\title{
Micro Small and Medium Enterprises Facing the Industry 4.0 Era in Semarang City
}

\author{
Karsinah $^{1}$, Yozi Aulia Rahman ${ }^{2}$, Phany Ineke Putri ${ }^{3}$ \\ \{iinkarsinah@mail.unnes.ac.id ${ }^{1}$, yoziaulia@mail.unnes.ac.id $\left.{ }^{2}\right\}$ \\ Universitas Negeri Semarang, Indonesia ${ }^{1,2,3}$
}

\begin{abstract}
The MSMEs sector contributes significantly to the economy of Semarang City. Besides contributing to the Semarang City gross regional domestic product, it also absorbs a significant amount of labor. Along with the development of industry 4.0, which leads to high-tech and the use of the Internet of Things (IoT), the MSMEs sector in Semarang City must adjust and prepare for changes. This research is an explorative study that focuses on identifying internal and external conditions, assessing readiness, and recommended strategies to the MSMEs facing the industry 4.0 era in Semarang City. The data used are quantitative data and qualitative data. In this study, the samples taken following the sampling technique are 100 micro and small business units. Quantitative descriptive analysis and Assessment Tool developed by Warwick University in England are used in the analysis method of this study. The results show that from three aspects of assessment, namely aspects of products and services, aspects of business models, and aspects of strategy and organization, the results of the readiness analysis are at level 2 (intermediate). With details on each aspect, namely aspects of products and services has a value of $(1,7)$. The business model aspect has a value of $(2,6)$ and the strategic and organizational aspects have a value of $(1,7)$.
\end{abstract}

Keywords: MSMEs, Industry 4.0, Semarang City, Economy, Aspects

\section{Introduction}

The evolution of the industry is developing rapidly over time. Prasetyo and Sutopo [1] state that the Industrial Revolution occurred four times, starting with the first industrial revolution in 1784. Industrial revolution 1.0 occurred in England with the invention of steam engines and manufacturing machines that replaced the role of human labor. Then, the 2.0 industrial revolution occurred when the use of electric power shifted to be the leading force driving production machines. The 3.0 industrial revolution occurred in the mid-1970s when the invention of computer technology affected the automation of the use of industrial machines. The industrial revolution 4.0 was first introduced in 2011 in Germany. The use of industrial technology in this era is more directed to the high-tech industry.

According to Marsudi and Wijaya [2], industrial revolution 4.0 has a significant impact on the results of the Mckinsey Global Institute study, specifically the use of robots and machines that impact the use of human labor. Regional governments have a strategic role in dealing with the development of industry 4.0, especially preparing industries in the region in order for them to continue having the strength to be competitive. One of them is Semarang City as a city based on trade and services following the initial plan of RPJMD of the Semarang City 2016-2021. With these development plans, it is expected that all stakeholders in the Semarang City, 
especially industry players, can be more adaptive in adjusting the times, especially industrial evolution, that increasingly focuses on the use of technology and computerization.

Businesses in big cities in Indonesia, especially Semarang City, are increasingly aware of the power of the internet and digital devices in improving business performance [3]. However, in reality, business people presently using the internet are indeed solely medium and large industries. Although these industries also have not implemented $100 \%$ of the internet. Website, social media, and mobile messaging applications are crucial media for MSMEs in interacting with consumers [3]. These tools have a role in advancing MSMEs in the era of disruption, yet MSMEs players have not fully realized them. The number of MSMEs increases every year, of course, becoming an excellent opportunity to develop the application of industry 4.0. The increase in the number of MSMEs in Semarang City is presented in table 1.

Table 1. Number of MSMEs in Semarang City by Sub-District In 2015-2017

\begin{tabular}{|c|l|c|c|c|}
\hline \multirow{2}{*}{ No } & \multirow{2}{*}{ Sub-District } & \multicolumn{3}{|c|}{ Year } \\
\cline { 3 - 5 } & & $\mathbf{2 0 1 5}$ & $\mathbf{2 0 1 6}$ & $\mathbf{2 0 1 7}$ \\
\hline 1 & Banyumanik & 79 & 328 & 206 \\
\hline 2 & Candisari & 24 & 149 & 219 \\
\hline 3 & Gajahmungkur & 27 & 235 & 171 \\
\hline 4 & Gayamsari & 24 & 287 & 413 \\
\hline 5 & Genuk & 31 & 325 & 271 \\
\hline 6 & Gunungpati & 34 & 126 & 191 \\
\hline 7 & Mijen & 18 & 79 & 144 \\
\hline 8 & Ngaliyan & 56 & 123 & 187 \\
\hline 9 & Pedurungan & 175 & 1.378 & 621 \\
\hline 10 & Semarang Barat & 65 & 315 & 416 \\
\hline 11 & Semarang Selatan & 155 & 185 & 368 \\
\hline 12 & Semarang Tengah & 23 & 206 & 378 \\
\hline 13 & Semarang Timur & 27 & 424 & 370 \\
\hline 14 & Semarang Utara & 70 & 235 & 474 \\
\hline 15 & Tembalang & 117 & 409 & 578 \\
\hline 16 & Tugu & 71 & 102 & 145 \\
\hline & Total & 996 & 4.906 & 5.152 \\
\hline
\end{tabular}

Source: Semarang in figure (2018).

Based on table 1, the number of MSMEs in Semarang City has increased every year, where the number of MSMEs in 2015 only amounted to 996, proceeded to increase to 4906 in 2016, and in 2017 to 5152 MSMEs. The existence of information and communication technology will create networking, thus minimizes the distance and time constraints and can be used to perform beneficial economic activities for its users. MSMEs can interact with consumers more easily if they utilize existing technology. Considering the many benefits that can be obtained from the existence of this technology, information, and communication, industries must implement it, especially in the Industry 4.0 Era. However, not all MSMEs can apply technology with a variety of obstacles encountered, such as the low level of human capital and performed innovations. In anticipating all of these problems, a study is necessary to assess the preparedness and strategies of MSMEs in Semarang City in facing the Industry 4.0 Era. 
From the problem formulation, this study aims to determine the internal and external conditions of MSMEs in Semarang City in overlooking the development of the Industry 4.0 Era and strategies that can be recommended.

\section{Research Methods}

This research is a quantitative descriptive study and uses primary data. The primary data used is a sample of MSMEs in Semarang City. The number of samples for MSMEs is 99 respondents. The respondent will fill out a questionnaire regarding the readiness of MSMEs in industry 4.0. The sample is distributed in 16 sub-districts throughout Semarang City. The aspects of Semarang City's MSME readiness to be analyzed refer to the industry 4.0 readiness assessment tool (An Industry Assessment Tool) developed by Warwick University in England [4]. Of the ten aspects, only three aspects will be assessed, considering that the three aspects are common conditions of the MSMEs in Indonesia. The three aspects are:

\subsection{Product and Services Aspect}

This aspect has several sub-indicators and readiness levels categorized into four levels from beginner to expert, including:

Table 2. Sub Indicators and Readiness Levels of Product and Service Aspects

\begin{tabular}{|c|c|c|c|c|}
\hline $\begin{array}{c}\text { Readiness } \\
\text { Level }\end{array}$ & $\begin{array}{c}\text { Level 1- } \\
\text { Beginner }\end{array}$ & $\begin{array}{c}\text { Level 2- } \\
\text { Intermediate }\end{array}$ & $\begin{array}{c}\text { Level 3- } \\
\text { Experienced }\end{array}$ & $\begin{array}{c}\text { Level 4- } \\
\text { Expert }\end{array}$ \\
\hline $\begin{array}{c}\text { Digital features } \\
\text { of products }\end{array}$ & $\begin{array}{c}\text { Only displaying } \\
\text { products } \\
\text { physically }\end{array}$ & $\begin{array}{c}\text { A small number of } \\
\text { products are displayed } \\
\text { digitally }\end{array}$ & $\begin{array}{c}\text { Most products } \\
\text { are displayed } \\
\text { digitally }\end{array}$ & $\begin{array}{c}\text { All products are } \\
\text { displayed } \\
\text { digitally }\end{array}$ \\
\hline $\begin{array}{c}\text { Data-driven } \\
\text { services }\end{array}$ & $\begin{array}{c}\text { There is no data- } \\
\text { based service }\end{array}$ & $\begin{array}{c}\text { There are data-based } \\
\text { services without } \\
\text { integration with } \\
\text { customers }\end{array}$ & $\begin{array}{c}\text { There are data- } \\
\text { based services } \\
\text { with limited } \\
\text { integration with } \\
\text { customers }\end{array}$ & $\begin{array}{c}\text { Data-based } \\
\text { services which } \\
\text { fully integrated } \\
\text { with customers }\end{array}$ \\
$\begin{array}{c}\text { Level of Product } \\
\text { Data Usage }\end{array}$ & $\begin{array}{c}\text { Product } \\
\text { information is } \\
\text { not displayed at } \\
\text { all }\end{array}$ & $\begin{array}{c}\text { The delivery level of } \\
\text { product information } \\
\text { is0-20\% }\end{array}$ & $\begin{array}{c}\text { The delivery } \\
\text { level of product } \\
\text { information } \\
\text { is }>20 \%-50 \%\end{array}$ & $\begin{array}{c}\text { The delivery } \\
\text { level of product } \\
\text { information is }> \\
50 \% .\end{array}$ \\
\hline
\end{tabular}

\subsection{Strategy and Organization Aspect}

This aspect has several sub-indicators and readiness levels which are categorized into four levels from beginner to expert, comprising:

Table 3. Sub Indicators and Level of Readiness for Strategic and Organizational Aspects

\begin{tabular}{|c|c|c|c|c|}
\hline $\begin{array}{c}\text { Readiness } \\
\text { Level }\end{array}$ & $\begin{array}{c}\text { Level 1- } \\
\text { Beginner }\end{array}$ & $\begin{array}{c}\text { Level 2- } \\
\text { Intermediate }\end{array}$ & $\begin{array}{c}\text { Level 3- } \\
\text { Experienced }\end{array}$ & $\begin{array}{c}\text { Level 4- } \\
\text { Expert }\end{array}$ \\
\hline $\begin{array}{c}\text { Degree of } \\
\begin{array}{c}\text { Strategy } \\
\text { Implementation }\end{array}\end{array}$ & $\begin{array}{c}\text { Industry 4.0 is } \\
\text { still in discussion }\end{array}$ & $\begin{array}{c}\text { Industry 4.0 is } \\
\text { included in the } \\
\text { strategy plan }\end{array}$ & $\begin{array}{c}\text { Industry 4.0 has } \\
\text { been applied and }\end{array}$ & $\begin{array}{c}\text { Industry 4.0 has } \\
\text { been applied and }\end{array}$ \\
\hline
\end{tabular}




\begin{tabular}{|c|c|c|c|c|}
\hline & & $\begin{array}{l}\text { company's } \\
\text { business }\end{array}$ & $\begin{array}{c}\text { communicated in } \\
\text { most parts/areas }\end{array}$ & $\begin{array}{l}\text { communicated to } \\
\text { all sections/areas }\end{array}$ \\
\hline Investment & $\begin{array}{l}\text { Investment of } \\
\text { industry } 4.0 \text { is still } \\
\text { restrained to } \\
\text { planning }\end{array}$ & $\begin{array}{c}\text { Investment of } \\
\text { Industry } 4.0 \text { in } \\
\text { one business area }\end{array}$ & $\begin{array}{c}\text { Investment of } \\
\text { Industry } 4.0 \text { in } \\
\text { most of business } \\
\text { area }\end{array}$ & $\begin{array}{c}\text { Investment of } \\
\text { industry } 4.0 \text { in the } \\
\text { business area }\end{array}$ \\
\hline $\begin{array}{c}\text { People } \\
\text { Capabilities }\end{array}$ & $\begin{array}{l}\text { Employees do not } \\
\text { possess the } \\
\text { experience of and } \\
\text { skills digital } \\
\text { technology }\end{array}$ & \begin{tabular}{|c|} 
A small \\
proportion of \\
employees \\
possess \\
experience and \\
expertise in \\
digital technology
\end{tabular} & \begin{tabular}{|} 
Most employees \\
possess digital \\
technology \\
experience and \\
skills
\end{tabular} & $\begin{array}{c}\text { All employees } \\
\text { possess experience } \\
\text { and digital } \\
\text { technology skills }\end{array}$ \\
\hline Leadership & $\begin{array}{c}\text { Company leaders } \\
\text { are not yet } \\
\text { interested in } \\
\text { Industry } 4.0\end{array}$ & $\begin{array}{c}\text { Company leaders } \\
\text { are conducting a } \\
\text { study of the } \\
\text { business }\end{array}$ & $\begin{array}{c}\text { Company leaders } \\
\text { are developing a } \\
\text { development plan } \\
\text { for industry } 4.0\end{array}$ & $\begin{array}{c}\text { Company leaders } \\
\text { support and } \\
\text { implement } \\
\text { industry } 4.0\end{array}$ \\
\hline
\end{tabular}

\subsection{Business Model Aspect}

This aspect has several sub-indicators and readiness levels which are categorized into four levels from beginner to expert comprising:

Table 4. Sub Indicators and Level of Readiness of the Business Model Aspects

\begin{tabular}{|c|c|c|c|c|}
\hline $\begin{array}{c}\text { Readiness } \\
\text { Level }\end{array}$ & $\begin{array}{c}\text { Level 1- } \\
\text { Beginner }\end{array}$ & $\begin{array}{c}\text { Level 2- } \\
\text { Intermediate }\end{array}$ & $\begin{array}{c}\text { Level 3- } \\
\text { Experienced }\end{array}$ & $\begin{array}{c}\text { Level 4- } \\
\text { Expert }\end{array}$ \\
\hline $\begin{array}{c}\text { Data-Driven } \\
\text { Decision }\end{array}$ & $\begin{array}{c}\text { Data is not } \\
\text { analyzed }\end{array}$ & $\begin{array}{c}\text { A small portion } \\
\text { of data is } \\
\text { analyzed }\end{array}$ & $\begin{array}{c}\text { Most of the data is } \\
\text { analyzed }\end{array}$ & $\begin{array}{c}\text { All relevant data are } \\
\text { analyzed and inform } \\
\text { the company's } \\
\text { business decisions }\end{array}$ \\
\hline $\begin{array}{c}\text { Real-time } \\
\text { Tracking }\end{array}$ & $\begin{array}{c}\text { Limited product } \\
\text { tracking }\end{array}$ & $\begin{array}{c}\text { Product tracking } \\
\text { extends to the } \\
\text { production } \\
\text { process and }\end{array}$ & $\begin{array}{c}\text { Product tracking } \\
\text { extends to the } \\
\text { market }\end{array}$ & $\begin{array}{c}\text { Complete product } \\
\text { tracking throughout } \\
\text { the business cycle }\end{array}$ \\
\hline $\begin{array}{c}\text { IT-supported } \\
\text { Business }\end{array}$ & $\begin{array}{c}\text { IT systems do } \\
\text { not yet support } \\
\text { business } \\
\text { processes }\end{array}$ & $\begin{array}{c}\text { Business } \\
\text { processes are } \\
\text { supported by IT } \\
\text { systems yet not } \\
\text { integrated }\end{array}$ & $\begin{array}{c}\text { Complete IT } \\
\text { support for all } \\
\text { processes yet not } \\
\text { fully integrated }\end{array}$ & $\begin{array}{c}\text { IT systems support } \\
\text { all company } \\
\text { business processes } \\
\text { and are integrated }\end{array}$ \\
\hline
\end{tabular}




\section{Results and Discussions}

\subsection{The readiness of MSMEs of Semarang City in the Industry 4.0 Era}

\subsubsection{Business Fields}

The distribution of business fields for Semarang City MSMEs is as follows:

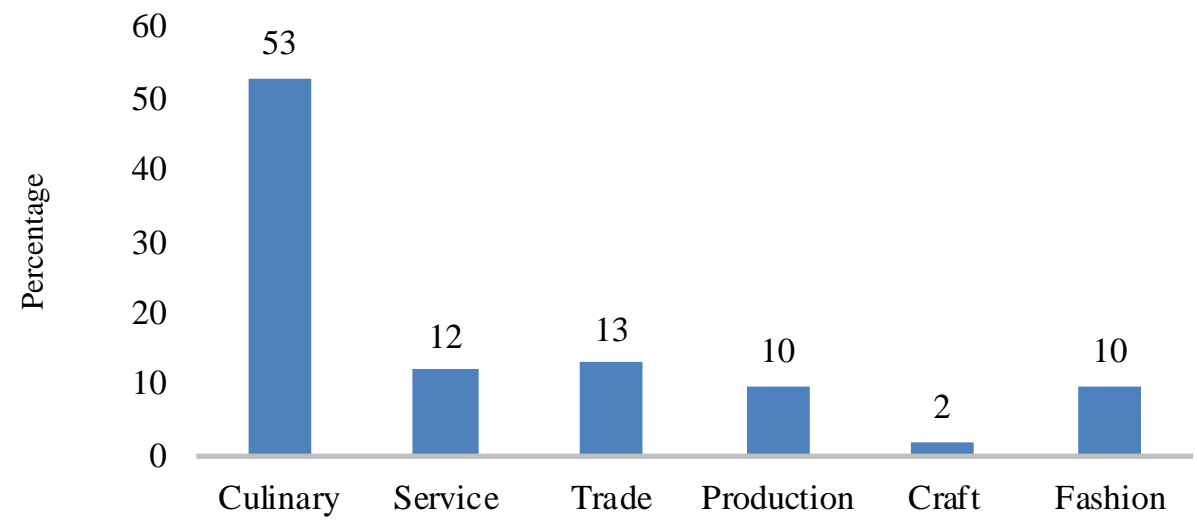

Fig. 1. MSMEs Business Fields in Semarang City.

Source: Primarily data, 2020.

Based on the graph above, of the 100 MSMEs respondents in Semarang City, the majority or $53 \%$ are culinary businesses, then trading businesses, such as grocery stores as much as $13 \%$. Service businesses such as laundry and salon services as much as $12 \%$. Fashion businesses such as tailors and small clothing stores as much as $10 \%$. Production business of $10 \%$ and handicraft business of $2 \%$.

\subsubsection{Evaluation of MSMEs Readiness of Product and Service Aspects}

Product and service aspects consist of four indicators, specifically (a) delivery of complete product information, (b) collaboration with large start-ups, (c) payment methods utilizing EDC (Electronic Data Capture), (d) payment methods through fintech. Based on the processing results, the following table shows the analysis of MSMEs' readiness in the aspects of products and services.

From the results Table 5 of primary data processing of respondents in Semarang City, from 100 MSMEs as many as $77 \%$ had submitted complete information about products to customers, while $23 \%$ of UMKM players had not submitted complete information. The next indicator is cooperation with big start-ups, only $25 \%$ of MSME players have collaborated, while the remaining $75 \%$ have not collaborated. The third indicator in the assessment of product and service aspects is the use of the EDC (Electronic Data Capture) payment method. The result shows only $22 \%$ of MSMEs in Semarang City have used the EDC payment method. 
Table 5. Evaluation of MSMEs Readiness of Product and Service Aspects

\begin{tabular}{|c|l|c|c|}
\hline No. & \multicolumn{1}{|c|}{ Product \& Service Aspects } & $\begin{array}{c}\text { Percentage of } \\
\text { Answer for Yes }\end{array}$ & $\begin{array}{c}\text { Percentage of } \\
\text { Answer for No }\end{array}$ \\
\hline 1. & $\begin{array}{l}\text { Complete information delivery regarding the } \\
\text { product to the customer }\end{array}$ & $77 \%$ & $23 \%$ \\
\hline 2. & Collaborate with big start-ups & $23 \%$ & $77 \%$ \\
\hline 3. & $\begin{array}{l}\text { Payment methods utilize EDC (Electronic } \\
\text { Data Capture) }\end{array}$ & $16 \%$ & $84 \%$ \\
\hline 4. & Payment methods through fintech & $12 \%$ & $84 \%$ \\
\hline
\end{tabular}

Source: Primary data, processed (2020)

The last indicator is the use of payment methods through fintech. From the results of the respondents' data, it is known that only 9\% of MSME actors use the fin-tech method, while the remaining $81 \%$ have not used the fin-tech payment method. There are several fin-tech companies that offer payment services to retail or small and medium enterprises (SMEs) at low cost. Most of the MSME in Semarang City cannot take advantage of this due to limited knowledge, skills and abilities.

\subsubsection{Evaluation of MSMEs Readiness from Business Models Aspect}

The business model aspect consists of 10 indicators, such as (a) franchises, (b) computer use, (c) laptops, (d) internet network facilities, (e) websites, (f) automatic machinery and equipment, $(\mathrm{g})$ report recordings of sales transactions, (h) bank accounts and (i) online banking facilities. Based on the processing results, the following table shows the analysis of MSMEs' readiness in the aspect of the business model presented in the following table 6.

Table 6. Evaluation of MSMEs Readiness of Business Models Aspect

\begin{tabular}{|c|l|c|c|}
\hline No. & \multicolumn{1}{|c|}{ Business Models Aspect } & $\begin{array}{c}\text { Percentage of } \\
\text { Answer for Yes }\end{array}$ & $\begin{array}{c}\text { Percentage of } \\
\text { Answer for No }\end{array}$ \\
\hline 1. & Franchise business & $17 \%$ & $83 \%$ \\
\hline 2. & Utilization of computer equipment & $55 \%$ & $45 \%$ \\
\hline 3. & Utilization of laptop equipment & $64 \%$ & $36 \%$ \\
\hline 4. & Internet network facilities & $42 \%$ & $58 \%$ \\
\hline 5. & Owning a personal website & $5 \%$ & $95 \%$ \\
\hline 6. & $\begin{array}{l}\text { Utilization of automatic machinery and } \\
\text { equipment }\end{array}$ & $33 \%$ & $67 \%$ \\
\hline 7. & Transaction report of recorded sales & $66 \%$ & $34 \%$ \\
\hline 8. & $\begin{array}{l}\text { Business financial transaction reports have } \\
\text { been presented periodically }\end{array}$ & $88 \%$ & $12 \%$ \\
\hline 9. & Owning a bank account & $81 \%$ & $19 \%$ \\
\hline 10. & Utilization of online banking facilities & $64 \%$ & $36 \%$ \\
\hline
\end{tabular}

Source: Primarily data, processed (2020).

Based on the results of processing, the following table shows the analysis of the readiness of MSMEs in the aspects of the business model shown in table 6. From primary data processing from respondents, it can be seen that most of the MSMEs in Semarang City do not yet have a franchise system, this of course will hamper the market expansion process of these MSMEs. However, most MSME also have computers/laptops, business financial transaction reports have 
been made regularly, already have bank accounts, and use online banking facilities such as mobile banking or internet banking.

\subsubsection{Evaluation of MSMEs Readiness from Strategic and Organizational Aspects}

The aspects of strategy and organization include nine aspects, which are presented in the following table 7 .

Table 7. Evaluation of MSMEs Readiness from Strategic and Organizational Aspects

\begin{tabular}{|c|l|c|c|}
\hline No. & \multicolumn{1}{|c|}{ Strategic and Organizational Aspects } & $\begin{array}{c}\text { Percentage of } \\
\text { Answer for Yes }\end{array}$ & $\begin{array}{c}\text { Percentage of } \\
\text { Answer for No }\end{array}$ \\
\hline 1. & $\begin{array}{l}\text { Business owners possess skills in utilizing } \\
\text { technology }\end{array}$ & $58 \%$ & $42 \%$ \\
\hline 2. & $\begin{array}{l}\text { Employees possess skills in utilizing } \\
\text { technology }\end{array}$ & $48 \%$ & $52 \%$ \\
\hline 3. & $\begin{array}{l}\text { Planning to invest in providing internet } \\
\text { facilities }\end{array}$ & $23 \%$ & $77 \%$ \\
\hline 4. & $\begin{array}{l}\text { Planning to purchase automated machinery } \\
\text { and equipment }\end{array}$ & $12 \%$ & $88 \%$ \\
\hline 5. & $\begin{array}{l}\text { Connected online with raw material } \\
\text { suppliers }\end{array}$ & $58 \%$ & $42 \%$ \\
\hline 6. & Connected online with consumers & $39 \%$ & $61 \%$ \\
\hline 7. & Owning a personal social media account & $48 \%$ & $52 \%$ \\
\hline 8. & Utilization of non-cash transactions & $22 \%$ & $78 \%$ \\
\hline 9. & $\begin{array}{l}\text { Employee's salary payout utilizing non- } \\
\text { cash }\end{array}$ & $20 \%$ & $80 \%$ \\
\hline
\end{tabular}

Source: Primarily data, processed (2020).

Based on the table 7, it explains the readiness of MSMEs from the strategic and organizational aspects. Business owners have proficiency in the use of technology by $58 \%$ of the total respondents, while employees who have skills in the use of technology are slightly lower by only $48 \%$. This shows that most actors and employees have not been able to properly utilize technology for the development of their business. In addition, non-cash payment of employee salaries was only $20 \%$ of the total respondents. This was also followed by the use of non-cash transactions, only $22 \%$ of the total respondents.

\subsubsection{The Readiness of MSMEs in the Industrial Era 4.0}

From the analysis of the MSME readiness assessment, seen from the aspects of products and services, aspects of business models, and aspects of strategy and organization, it can be concluded that the readiness of the MSMEs sector in facing the industrial era 4.0 is at level 2. As can be seen in Figure 2. 


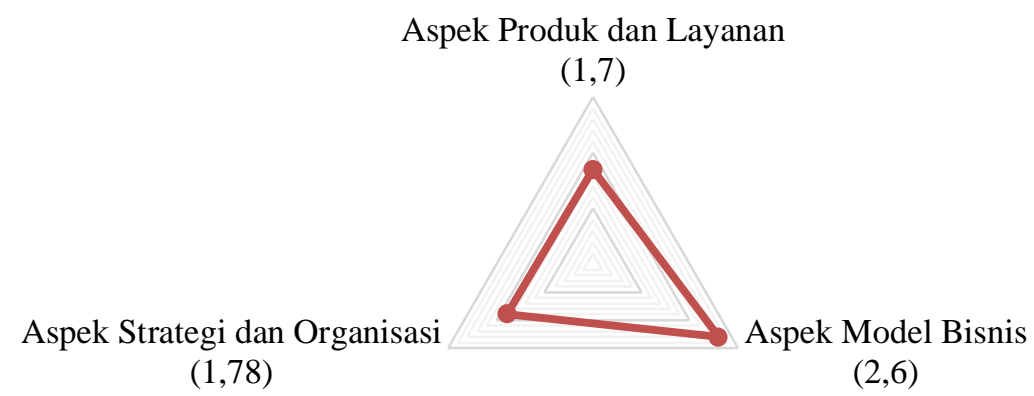

Fig. 2. The Readiness of MSMEs in the Industrial Era 4.0.

Source: processed data, 2020

From three aspects of assessment, namely aspects of products and services, aspects of business models, and aspects of strategy and organization, the results of the readiness analysis are at level 2 (intermediate). With details on each aspect, namely aspects of products and services has a value of $(1,7)$. The business model aspect has a value of $(2,6)$ and the strategic and organizational aspects have a value of $(1,7)$.

\section{Conclusions}

The readiness of the industrial sector of Semarang City in facing the Industry 4.0 Era is at level 2 or intermediate. With details on each aspect, namely aspects of products and services has a value of $(1,7)$. The business model aspect has a value of $(2,6)$ and the strategic and organizational aspects have a value of $(1,7)$.

With details on each aspect, namely aspects of products and services has a value of 1.7. This means that most MSME respondents have not collaborated with large start-ups, and have not utilized EDC (Electronic Data Capture) or fin-tech payment methods. Most MSME are reluctant to collaborate with start-ups such as Gojek, Grab or other start-ups, this is because MSMEs do not have complete information about cooperation with start-ups, besides that there is a sharing of the profits from sales with start-up companies. ups if doing cooperation.

The business model aspect has a value of 2.6, this is indicated by most of the respondents of MSMEs already have a recorded sales transaction report, business financial transaction reports have been made periodically, besides that MSME also already have bank accounts and use online bank facilities such as mobile banking or Internet banking. However, most MSMEs do not have a franchise business, do not have their own website, and do not use automatic machines and equipment. This will make it difficult for MSME to develop if they want to expand their business.

The strategic and organizational aspects have a value of 1.7 , this is indicated by more than $58 \%$ of the respondents of MSME business owners have proficiency in technology and are connected online with raw material suppliers. However, most MSME respondents have not used non-cash transactions either in running their business or for employee payroll, besides that, 
MSMEs have not invested in purchasing automatic machines and equipment, and have not been connected online with customers.

\section{Recommendations}

1. It is necessary to socialize the concept of industry 4.0 more massively to MSME players in the city of Semarang.

2. Efforts should be made to increase investment in industry 4.0 by using more high-tech machines or tools. Provision of funds for investment can work with the banking sector.

3. There needs to be an increase in industrial literacy 4.0 to the people of Semarang City, such as the use of applications to help with daily activities, such as the use of electronic money or electronic wallets.

\section{References}

[1] H. Prasetyo and W. Sutopo, "Industri 4.0: Telaah Klasifikasi aspek dan arah perkembangan riset," J@ ti Undip J. Tek. Ind., vol. 13, no. 1, pp. 17-26, 2018.

[2] A. S. Marsudi and Y. Widjaja, "Industri 4.0 dan dampaknya terhadap financial technology serta kesiapan tenaga kerja di Indonesia," Ikra-Ith Ekon., vol. 2, no. 2, pp. 1-10, 2019.

[3] Deloitte, "UKM Pemicu Kemajuan Indonesia: Instrumen Pertumbuhan Nusantara," Deloitte Access Econ., pp. 1-56, 2015.

[4] Warwick University, "An Industri 4 Readiness Assessment Tool,” Warwick University, 2017. [Online]. Available: https://warwick.ac.uk/fac/sci/wmg/research/scip/industri4report/. 